\title{
FORECASTING MIGRATION \\ FLOWS FOR NEW ZEALAND: \\ ARRIVALS OF NEW AND \\ RETURNING NEW ZEALANDERS \\ \& DEPARTURES BY \\ DESTINATIONS
}

\author{
Xintao Zhao, Ram SriRamaratnam and \\ Dirk van Seventer
}

\author{
Department of Labour \\ Wellington
}

\begin{abstract}
The purpose of this paper was to outline the methods and to report results of an econometric attempt to forecast New Zealand migration flows. Flows were decomposed into eight components: two relating to arrivals and six components relating to departures by several destinations. Linear time series regression and the Holt-Winters exponential smoothing method were applied to quarterly data from June 1978 to June 2008 or from March 1990 to June 2008. Within-sample mean absolute percentage errors were presented and full-sample estimates from June 1978 to September 2010 or from March 1990 to September 2010 were used to forecast migration flows for each component for the next two years.
\end{abstract}

\section{Introduction}

Migration flows are important for monitoring the New Zealand labour market and feature prominently in a range of labour market reports from the Department of Labour (DoL). This paper aims to construct an appropriate disaggregated framework for forecasting migration flows to and from New Zealand. This was considered quite important to understand better the factors which influenced migration flows in the past and likely to in the future.

Thomson and Chan (1999) undertook some work on forecasting migration flows to and from New Zealand. In their paper, they decomposed permanent and longterm migration flows into six components: (1) Arrivals of New Zealanders, (2) Arrivals of non-New Zealanders with restricted access, (3) Arrivals of nonNew Zealanders with unrestricted access, (4) Departures of New Zealanders, (5) Departures of nonNew Zealanders with restricted access, and (6) Departures of non-New Zealanders with unrestricted access. In addition, they made a distinction between "primary flow" and "return flow". Primary flow meant the first leg of the journey of migrants from the source country. Return flow showed the second leg journey when migrants return to their source country. Return flow could be forecasted by using the primary flow as an independent variable. However, they did not investigate the likely impact of economic push and pull factors on migration flows in their study.
As an extension of the Thomson and Chan (1999) analysis, we decomposed New Zealand migration flows into eight components: two relating to arrivals and six components relating to departures with the latter identifying three destinations. The two components relating to arrivals were: (1) Arrivals of non-New Zealanders (ANNZ) or new migrants and (2) Arrivals (or Return) of New Zealanders (RNZ). The new migrants have to be processed by the New Zealand Immigration Service but the movement of New Zealand citizens is unrestricted. It is often influenced by economic and some circular factors (i.e. previous departures resulting in subsequent arrivals).

The six components related to departures were: Departures of non-New Zealanders and New Zealanders to (1) Australia (DNNZTA and DNZTA), (2) the United Kingdom (DNNZTU and DNZTU), and (3) the rest of the world (DNNZTRW and DNZTRW). Australia and the UK are the two main destinations of long-term permanent migrants from New Zealand. This decomposition enabled us to consider country specific economic push and pull variables as well as circular factors to explain departures to these destinations.

In the last five years, the average departures to Australia and the UK by New Zealand citizens accounted for about $68 \%$ and $14 \%$, respectively. The average departure to the UK has been declining over time and the UK shares were much higher in the earlier part of the 30 year data period covered such as the 
1980s and the 1990s. We decided to study Australia and the UK as separate destinations of long-term permanent migrants from New Zealand with the remaining included in a combined Rest-of the World category. The above decomposition enabled us to conveniently apply economic push and pull variables to explain departures of migrants to Australia and the UK.

\section{Methodology and Data}

In this paper, the forecasting methods we used are linear time series regression and the Holt-Winters exponential smoothing method. The eight migration components estimated covered quarterly data from June 1978 to September 2010, with the exception of the New Migrant Arrivals data from March 1990 to September 2010, sourced from Statistics New Zealand. All the eight sets of time series exhibited seasonality of varying degrees on visual inspection.

In the case of all migration components except for New Zealanders departures to Australia and the UK, linear time series regression method was applied. Because the above six sets of data were not stationary, we first isolated the seasonal difference of $\log$ values of the six migration components by estimating the changes for the same quarters. Then we transformed this data by deriving the first differences of the seasonal differences in order to achieve sets of data which was stationary. In the six linear time series equations, the dependent variables were the differences of $\log$ values of the six migration components. The majority of the independent variables were lagged values of the corresponding dependent variables with lags ranging from one to twenty quarters being considered. This could be described as capturing the "momentum effect".

In the case of the migration equation of returning New Zealanders, an additional independent variable that was considered was the differences of $\log$ values of total New Zealanders departures in previous quarters. This approach was analogous to the link between primary and return flows made by Thomson and Chan (1999). Similarly in the case of migration equations covering the departures of non-New Zealanders to Australia and the UK, lag values of differences of log values of nonNew Zealanders arrivals were included to represent some circular migration. In order to derive the above differences, we used the same transformation as mentioned in last paragraph to achieve stationary data.

For the two migration equations covering departures of non-New Zealanders for Australia and the UK, the following economic push and pull factors were also included as additional independent variables: (i) the ratios between the changes in New Zealand GDP per capita and Australian GDP per capita (RCNZAG), (ii) the ratios between the changes in New Zealand and Australian civilian employment levels (RCNZACEL), (iii) the ratios between the changes in New Zealand GDP per capita and British GDP per capita (RCNZBG) and (iv) the ratios between the changes in New Zealand and British civilian employment levels (RCNZBCEL).

The ratios between the changes in New Zealand GDP per capita and the Australian GDP per capita and the ratios between the changes in New Zealand GDP per capita and British GDP per capita, covered the period from June 1978 to June 2010. The ratios between the changes in New Zealand and Australian civilian employment levels and the ratios between the changes in New Zealand and British civilian employment levels covered the period from March 1986 to June 2010. All of these ratios were stationary.

In the case of New Zealanders departures to Australia and the UK, it was not possible to estimate a suitable linear time series regression equations. Hence the HoltWinters method was considered as an alternative method to forecast quarterly flows of New Zealanders departures to Australia and the UK. This method essentially takes simple exponential smoothing as starting points and also accounts for trend and seasonal factors. Because the data showed seasonality, we considered a seasonal additive Holt-Winters method and a seasonal multiplicative Holt-Winters method as two possible options.

Our overall forecasting approach used for the eight migration components is as follows:

(A) First we applied linear time series regression method or the Holt-Winters exponential smoothing method for quarterly data from June 1978 to June 2008 or from March 1990 to June 2008. Then we estimated the withinsample linear equations for six migration components and used them to forecast six migration components for nine quarters from September 2008 to September 2010. Using the Holt-Winters method, we also obtained the forecasts of New Zealanders departures to Australia and the UK from September 2008 to September 2010.

(B) The next step was to calculate the mean absolute percentage errors (MAPEs) by comparing the corresponding forecast and actual values for the nine quarters from September 2008 to September 2010.

(C) Finally by using quarterly data from June 1978 to September 2010 or from March 1990 to September 2010, the eight full-sample migration components were estimated; linear time series regression method used for six components and the Holt-Winters method applied to forecast the seventh and eighth migration components and quarterly forecasts were made for the period from December 2010 to September 2012 or December 2012.

The detailed description of data sources used was included in Appendix A. The quarterly forecasts and the corresponding annual forecasts and respective actual figures were provided in Appendix B. 
Results

Within-sample equations, Holt-Winters Method and mean absolute percentage errors (MAPEs)
Table 1 presented within-sample equations for six migration components.

Table 1: Within-sample Time Series Equations for Six Migration Components

\begin{tabular}{|c|c|c|c|c|c|c|}
\hline \multirow{2}{*}{$\begin{array}{l}\text { Within-sample equation } \\
\text { Independent Variables } \\
\end{array}$} & \multicolumn{2}{|c|}{$\begin{array}{l}\text { Difference of Log } \\
\text { Values of Non-New } \\
\text { Zealanders and New } \\
\text { Zealanders Arrivals }\end{array}$} & \multicolumn{3}{|c|}{$\begin{array}{l}\text { Difference of Log Values of Non-New } \\
\text { Zealanders Departures to Australia, the UK } \\
\text { and the Rest of the World }\end{array}$} & \multirow[t]{2}{*}{$\begin{array}{l}\text { Difference } \\
\text { of Log } \\
\text { Values of } \\
\text { New } \\
\text { Zealanders } \\
\text { Departures } \\
\text { for the } \\
\text { Rest of the } \\
\text { World } \\
\text { Eq. } 6 \\
\end{array}$} \\
\hline & Eq. 1 & Eq. 2 & Eq. 3 & Eq. 4 & Eq. 5 & \\
\hline $\begin{array}{l}\text { 1. Lagged Dependent } \\
\text { Variable }\end{array}$ & & & & & & \\
\hline $\mathrm{t}-1$ & & & & & $-0.225^{* *}$ & $-0.179 * *$ \\
\hline $\mathrm{t}-3$ & & & & & $0.378 * * *$ & \\
\hline $\mathrm{t}-4$ & $-0.350 * *$ & $-0.487 * * *$ & $-0.677 * * *$ & $-0.631 * * *$ & $-0.259 * * *$ & $-0.576^{* * *}$ \\
\hline $\mathrm{t}-6$ & & & & $0.222 * * *$ & & \\
\hline $\mathrm{t}-7$ & & & & & & $-0.192 * *$ \\
\hline $\mathrm{t}-8$ & $-0.515 * * *$ & $-0.345 * * *$ & $-0.456 * * *$ & $-0.481 * * *$ & $-0.294 * * *$ & $-0.431 * * *$ \\
\hline $\mathrm{t}-12$ & $-0.238^{*}$ & $-0.251 * *$ & $-0.355 * * *$ & $-0.309 * * *$ & & $-0.264 * *$ \\
\hline $\mathrm{t}-16$ & $-0.504 * * *$ & & & & & $-0.232 * * *$ \\
\hline $\mathrm{t}-18$ & & $-0.173 * *$ & & & $-0.185^{* *}$ & \\
\hline t-19 & & & & $-0.150^{*}$ & & \\
\hline$t-20$ & $-0.291 * *$ & & $-0.185 * *$ & $-0.205^{* * *}$ & & \\
\hline $\begin{array}{l}\text { 2. Differences of Log } \\
\text { Values of Total New } \\
\text { Zealanders Departures }\end{array}$ & & & & & & \\
\hline $\mathrm{t}-13$ & & $-0.150 * *$ & & & & \\
\hline $\begin{array}{l}\text { 3. Difference of Log } \\
\text { Values of Non-New } \\
\text { Zealanders Arrivals }\end{array}$ & & & & & & \\
\hline $\mathrm{t}-8$ & & & & $0.380 * * *$ & & \\
\hline $\mathrm{t}-15$ & & & $-0.285^{* *}$ & & & \\
\hline $\begin{array}{l}\text { 4. The Ratios between } \\
\text { the Changes of New } \\
\text { Zealand GDP per } \\
\text { Capita and Australian } \\
\text { GDP per Capita }\end{array}$ & & & & & & \\
\hline $\mathrm{t}-9$ & & & $-0.003^{*}$ & & & \\
\hline $\begin{array}{l}\text { 5. The Ratios between } \\
\text { the Changes of New } \\
\text { Zealand and Australian } \\
\text { Civilians Employment }\end{array}$ & & & & & & \\
\hline $\mathrm{t}-17$ & & & $-0.009 * *$ & & & \\
\hline $\begin{array}{l}\text { 6. The Ratios between } \\
\text { the Changes of New } \\
\text { Zealand GDP per } \\
\text { Capita and British GDP } \\
\text { per Capita }\end{array}$ & & & & & & \\
\hline $\mathrm{t}-12$ & & & & $-1.85 \times 10^{-5} * * *$ & & \\
\hline R-squared & 0.378 & 0.349 & 0.566 & 0.480 & 0.417 & 0.386 \\
\hline Adjusted R-squared & 0.313 & 0.313 & 0.519 & 0.432 & 0.386 & 0.347 \\
\hline $\mathrm{F}$ & 5.831 & 9.844 & 12.091 & 10.037 & 13.187 & 9.761 \\
\hline AIC & -2.302 & -2.370 & -1.826 & -1.690 & -1.875 & -2.041 \\
\hline
\end{tabular}

$*, * *, * * *$ denote the coefficients significant at $10 \%, 5 \%$ and $1 \%$ respectively. 
Table 2: The Results from Holt-Winters Method for New Zealanders Departures to Australia (June 1978 to June 2008)

\begin{tabular}{|c|c|}
\hline 1. Parameter & \\
\hline Alpha (Mean) & 1.00 \\
\hline Beta (Trend) & 0.00 \\
\hline Gamma (Seasonality) & 0.00 \\
\hline 2. Sum of Squared Residuals & $88,109,910.00$ \\
\hline 3. Root Mean Squared Error & 853.34 \\
\hline
\end{tabular}

Tables 2 and 3 showed the results from seasonal multiplicative Holt-Winters exponential smoothing method for within-sample estimation applied for New Zealanders departures to Australia and the UK from June 1978 to June 2008. We tried both the seasonal additive and multiplicative Holt-Winters Methods for the above within-sample data respectively. The results from the latter were much better than those from the former. The seasonal multiplicative Holt-Winters method was therefore chosen for forecasting purposes. In Table 2, we could see that Beta and Gamma were about 0 , meaning the trend and seasonality were very small. Similarly in Table 3, the trend was very small as Beta is about 0 .

\section{Model Validation}

In this section, the estimated results from the within sample and full sample equations were reported and the goodness of fit of the overall equations as well as the significance of the individual coefficients were assessed. This model validation process was critical for evaluating the ability of these estimated equations to produce consistent out of sample forecasts.

Table 4 presented the mean absolute percentage errors (MAPEs) for all of the eight migration components derived from the within sample (to June quarter 2008) equations. The dependent variables were estimated using data from June 1978 to June 2008 except for the new migrant equation which was from January 1990.
Table 3: The Results Holt-Winters Method from for New Zealanders Departures to the UK (June 1978 to June 2008)

\begin{tabular}{|c|c|}
\hline 1. Parameter & \\
\hline Alpha (Mean) & 0.80 \\
\hline Beta (Trend) & 0.00 \\
\hline Gamma (Seasonality) & 0.24 \\
\hline 2. Sum of Squared Residuals & $5,366,456.00$ \\
\hline 3. Root Mean Squared Error & 210.60 \\
\hline
\end{tabular}

Based on these equations, quarterly forecasts were derived for the quarterly periods from September 2008 to September 2010 for six migration components. In addition, the equations on New Zealanders departures to Australia and the UK using quarterly data from June 1978 to June 2008, the seasonal multiplicative HoltWinters method was applied (See Tables 2 and 3) to arrive at the quarterly forecasts from September 2008 to September 2010.

Using actual data and their corresponding forecasts, we calculated mean absolute percentage errors (MAPEs) for all migration components (See Table 4). For the first five equations, their MAPEs all were below $8 \%$. For equation 6, its MAPE was over $10 \%$ but still reasonable. For New Zealanders departures to Australia and the UK, the MAPEs from seasonal multiplicative Holt-Winters methods were $26.5 \%$ and $39.6 \%$. Although high, they were better than any other estimations which were tried.

In table 5 estimated full-sample equations for six migration components were presented. This resulted in 36 different explanatory variables (majority of them lagged dependent variables) being considered as significant at least at the $10 \%$ level of confidence. Out of the 36 coefficients estimated across the six linear time series regressions, 22 (or 61\%) were significant at the (highest) $1 \%$ level of confidence and another 11 (or $31 \%$ ) were significant at the $5 \%$ level of confidence.

Table 4: Mean Absolute Percentage Errors: Linear Equations and Holt-Winters Method

\begin{tabular}{|c|c|c|}
\hline (Within-sample) or Holt Winters Method & Migration Components & MAPE \\
\hline Eqrivals: & Non-New Zealanders (New Migrants) & $5.3 \%$ \\
\hline Equation 1 & Returning New Zealanders & $3.0 \%$ \\
\hline Departures of Non-New Zealanders: & for Australia & $7.9 \%$ \\
\hline Equation 3 & for the UK & $4.1 \%$ \\
\hline Equation 4 & for the Rest of the World & $6.6 \%$ \\
\hline Equation 5 & for Australia & \\
\hline Departures of New Zealanders: & for the UK & $26.5 \%$ \\
\hline Holt-Winters Method & for the Rest of the World & $39.6 \%$ \\
\hline Holt-Winters Method & & $14.0 \%$ \\
\hline Equation 6 & & \\
\hline
\end{tabular}


Forecasts from Full-sample Equations or

Holt-Winters Method

Table 5: Full-sample Time Series Equations for Six Migration Components

\begin{tabular}{|c|c|c|c|c|c|c|}
\hline \multirow[t]{2}{*}{$\begin{array}{c}\text { Full-sample equation } \\
\text { Independent Variables }\end{array}$} & \multicolumn{2}{|c|}{$\begin{array}{l}\text { Difference of Log } \\
\text { Values of Non-New } \\
\text { Zealanders and New } \\
\text { Zealanders Arrivals }\end{array}$} & \multicolumn{3}{|c|}{$\begin{array}{l}\text { Difference of Log Values of Non-New } \\
\text { Zealanders Departures to Australia, the UK } \\
\text { and the Rest of the World }\end{array}$} & $\begin{array}{l}\text { Difference } \\
\text { of Log } \\
\text { Values of } \\
\text { New } \\
\text { Zealanders } \\
\text { Departures } \\
\text { for the } \\
\text { Rest of the } \\
\text { World }\end{array}$ \\
\hline & Eq. 1 & Eq. 2 & Eq. 3 & Eq. 4 & Eq. 5 & Eq. 6 \\
\hline \multicolumn{7}{|l|}{$\begin{array}{l}\text { 1. Lagged Dependent } \\
\text { Variable }\end{array}$} \\
\hline $\mathrm{t}-1$ & & & & & $-0.228 * *$ & $-0.155^{*}$ \\
\hline $\mathrm{t}-3$ & & & & & $0.374 * * *$ & \\
\hline $\mathrm{t}-4$ & $-0.375 * * *$ & $-0.486 * * *$ & $-0.704 * * *$ & $-0.621 * * *$ & $-0.264 * * *$ & $-0.577 * * *$ \\
\hline $\mathrm{t}-6$ & & & & $0.228^{* * *}$ & & \\
\hline $\mathrm{t}-7$ & & & & & & $-0.198 * *$ \\
\hline $\mathrm{t}-8$ & $-0.514 * * *$ & $-0.352 * * *$ & $-0.455^{* * *}$ & $-0.478 * * *$ & $-0.288 * * *$ & $-0.435 * * *$ \\
\hline $\mathrm{t}-12$ & $-0.257 * *$ & $-0.250^{* *}$ & $-0.344 * * *$ & $-0.307 * * *$ & & $-0.254 * *$ \\
\hline $\mathrm{t}-16$ & $-0.470 * * *$ & & & & & $-0.225 * * *$ \\
\hline $\mathrm{t}-18$ & & $-0.163 * *$ & & & $-0.168 * *$ & \\
\hline $\mathrm{t}-19$ & & & & $-0.152 *$ & & \\
\hline$t-20$ & $-0.317 * * *$ & & $-0.160 * *$ & $-0.209 * * *$ & & \\
\hline \multicolumn{7}{|l|}{$\begin{array}{l}\text { 2. Differences of Log } \\
\text { Values of Total New } \\
\text { Zealanders Departures }\end{array}$} \\
\hline $\mathrm{t}-13$ & & $-0.170^{* *}$ & & & & \\
\hline \multicolumn{7}{|l|}{$\begin{array}{l}\text { 3. Difference of Log } \\
\text { Values of Non-New } \\
\text { Zealanders Arrivals }\end{array}$} \\
\hline $\mathrm{t}-8$ & & & & $0.384 * * *$ & & \\
\hline$t-15$ & & & $-0.281 * *$ & & & \\
\hline \multicolumn{7}{|l|}{$\begin{array}{l}\text { 4. The Ratios between } \\
\text { the Changes of New } \\
\text { Zealand GDP per } \\
\text { Capita and Australian } \\
\text { GDP per Capita }\end{array}$} \\
\hline $\mathrm{t}-9$ & & & $-0.003^{*}$ & & & \\
\hline \multicolumn{7}{|l|}{$\begin{array}{l}\text { 5. The Ratios between } \\
\text { the Changes of New } \\
\text { Zealand and Australian } \\
\text { Civilians Employments }\end{array}$} \\
\hline $\mathrm{t}-17$ & & & $-0.009 * *$ & & & \\
\hline \multicolumn{7}{|l|}{$\begin{array}{l}\text { 6. The Ratios between } \\
\text { the Changes of New } \\
\text { Zealand GDP per } \\
\text { Capita and British GDP } \\
\text { per Capita }\end{array}$} \\
\hline $\mathrm{t}-12$ & & & & $-1.87 \times 10^{-5} * * *$ & & \\
\hline R-squared & 0.368 & 0.353 & 0.543 & 0.483 & 0.405 & 0.370 \\
\hline Adjusted R-squared & 0.312 & 0.321 & 0.500 & 0.4402 & 0.378 & 0.333 \\
\hline $\mathrm{F}$ & 6.634 & 11.015 & 12.571 & 11.196 & 13.761 & 9.980 \\
\hline AIC & -2.337 & -2.446 & -1.874 & -1.764 & -1.925 & -2.034 \\
\hline
\end{tabular}

$*, * *, * * *$ denote the coefficients significant at $10 \%, 5 \%$ and $1 \%$ respectively. 
The detailed full-sample equations could be seen in Appendix C. The dependent variables used in the quarterly equations reported in table 5 covered the June 1978 to September 2010 period, with the exception of the New Migrant Arrivals equation which used more recent data from March 1990 to September 2010.

Table 6: The Results from Holt-Winters Method for New Zealanders Departures to Australia (From June 1978 to September 2010)

\begin{tabular}{|c|c|}
\hline 1. Parameter & \\
\hline Alpha (Mean) & 1.00 \\
\hline Beta (Trend) & 0.00 \\
\hline Gamma (Seasonality) & 0.00 \\
\hline 2. Sum of Squared Residuals & $103,000,000.00$ \\
\hline 3. Root Mean Squared Error & 893.79 \\
\hline
\end{tabular}

Table 7: The Results from Holt-Winters Method for New Zealanders Departures to the UK(From June 1978 to September 2010)

\begin{tabular}{|c|c|}
\hline 1. Parameter & \\
\hline Alpha (Mean) & 0.86 \\
\hline Beta (Trend) & 0.00 \\
\hline Gamma (Seasonality) & 0.01 \\
\hline 2. Sum of Squared Residuals & $5,882,356.00$ \\
\hline 3. Root Mean Squared Error & 212.72 \\
\hline
\end{tabular}

Table 6 and Table 7 presented the results from seasonal multiplicative Holt-Winters method for full-sample applied for New Zealanders departures to Australia and the UK from June 1978 to September 2010. Based on the above full-sample equations and Holt-Winters methods, we derived quarterly forecasts from March 2000 to September 2012 or December 2012 for eight migration components. They were presented in the following Figures 1 through to Figure 5, respectively.

\section{Forecasts (Including Out-of-sample) and Comparison with Actual Data}

\section{A: Arrivals}

Figure 1: Actual and Forecast Numbers of New and Return Arrivals in New Zealand

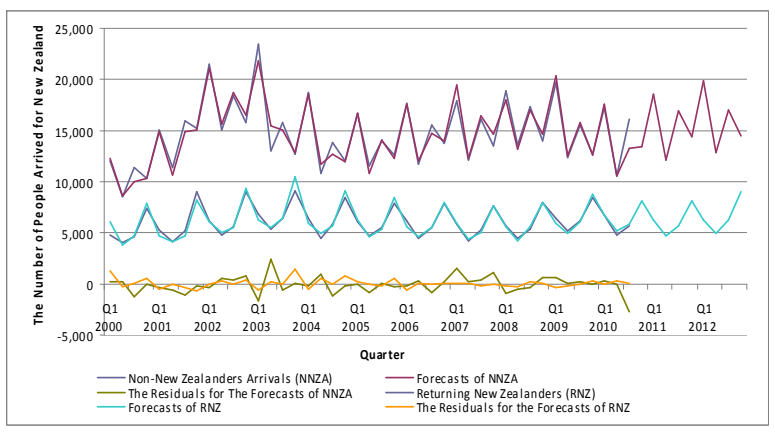

Figure 1 presented actual data and forecasts from fullsample equations for arrivals of new migrants or non-
New Zealanders and the arrivals or return of New Zealanders, respectively. It also showed the residuals of the full-sample equations for non-New Zealanders arrivals and returning New Zealanders. Data of nonNew Zealanders arrivals and returning New Zealanders demonstrated strong seasonality. From figure 1, it could also be seen that there was significantly more fluctuations for arrivals of non-New Zealanders than those for returning New Zealanders. Over the period from March 2000 to September 2010 (historical period), the correspondence between actual values and forecasts of returning New Zealanders was much better than that of new migrants or non-New Zealander arrivals.

The arrivals of non-New Zealanders were forecast to December 2012 and expected to fluctuate between about 12,000 and 20,000, while the returning New Zealander numbers were forecast to September 2012 and expected to fluctuate between about 4,500 and 8,000 . The detailed quarterly forecasts of the above two migration components were provided in Table 6 of Appendix B.

\section{B: Departures-Non-New Zealanders}

Figure 2: Actual and Forecast Numbers of Non-New Zealanders to Australia

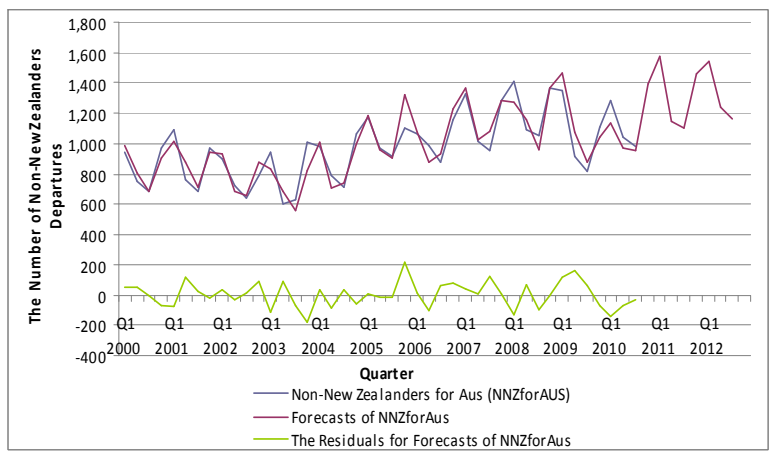

Figure 3: Actual and Forecast Data of Non-New Zealanders to the UK and the Rest of the World

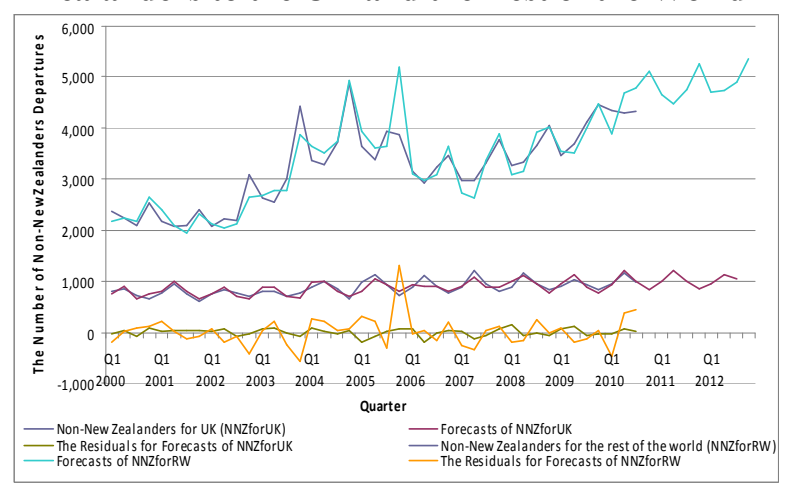

Figure 2 showed actual data, forecasts and residuals from the full-sample equation of non-New Zealanders departures to Australia. The level of non-New Zealanders departures to Australia to September 2012 was forecast to fluctuate between about 900 and 1,400. 
Figure 3 presented actual data and forecasts from fullsample equations of non-New Zealanders departures to the UK and the rest of the world, respectively. It also presented the residuals of the two full-sample equations separately. It could be seen that the departures of nonNew Zealanders to the UK forecast to September 2012 and expected to fluctuate between about 850 and 1,200. The departures of non-New Zealanders to the rest of the world forecast to December 2012 were expected to fluctuate between 4,700 and 5,400. All data in figures 2 and 3 demonstrated seasonality. The detailed quarterly forecasts of the above three migration components could be seen in Table 7 of Appendix B.

\section{C: Departures-New Zealanders}

Figure 4: Actual and Forecast Numbers of New Zealanders for Australia and the UK

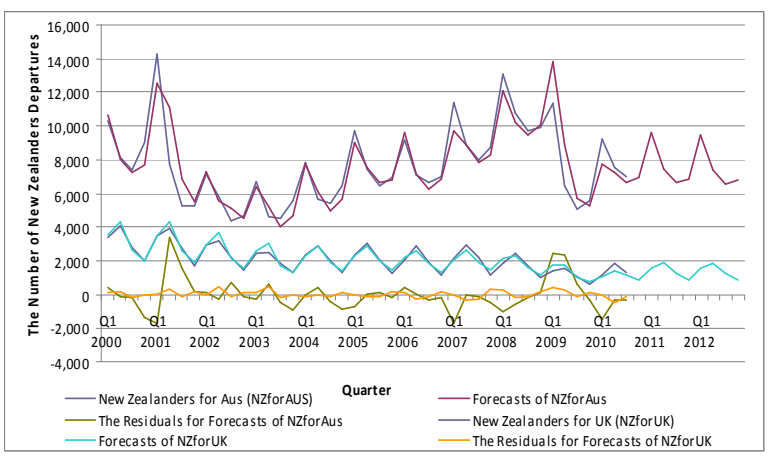

Figure 4 presented actual data and forecasts from fullsample equations of New Zealanders departures to Australia and the UK, respectively. It also showed the residuals separately. The forecasts were derived with the seasonal multiplicative Holt-Winters exponential smoothing method. These two sets of data also exhibited very strong seasonal pattern of migration of New Zealanders to Australia and the UK. In figure 4, the departures of New Zealanders to Australia forecast to September 2012 fluctuated between about 6,600 and 9,600 . New Zealanders departures to the UK forecast to December 2012 fluctuated between about 850 and 1,900. The detailed quarterly forecasts of the above two migration components could also be found in Table 7 of Appendix B.

Figure 5: Actual and Forecast Numbers of New Zealanders for the Rest of the World

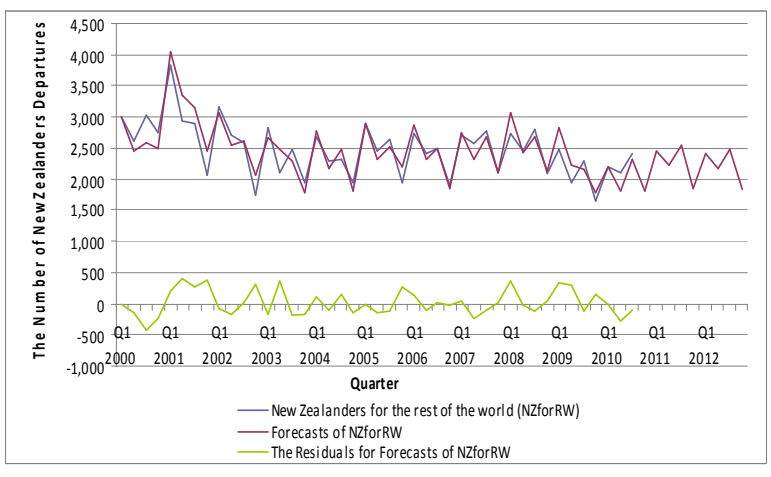

Figure 5 showed actual data, forecasts and the residuals from the full-sample equation of New Zealanders departures to the rest of the world. This set of data also demonstrated very strong seasonal pattern. In figure 5, the actual departures of New Zealanders to the rest of the world forecast to December 2012 fluctuated between 1,800 and 2,500. The detailed quarterly forecasts of the above migration component could also be seen in Table 7 of Appendix B.

\section{Summary}

In summary, forecasts of total arrivals and total departures for September 2011 and 2012 years and all years in between could also be generated. In table 8 of Appendix B, actual total arrivals for 2008 to 2010 September years were 86,657, 87,209 and 82,412, respectively. This represented fluctuation of the annual figure within a narrow band initially but some decline in September 2010 year. For September 2011 and 2012 years, forecast of total arrivals were about 86,000 and 90,000 , respectively, which suggested some recovery in arrivals during September 2012 year in particular. Considering the actual data and forecasts, total arrivals peaked in the September 2009 year. Following this, total arrivals decreased during September 2010 year but were forecast to rise somewhat during September 2011 year and September 2012 year.

Actual total departures from September 2008 year to September 2010 year were 82,271, 70,184 and 68,501. Forecasts of total departures for September 2011 and 2012 years were about 75,000 and 75,300 respectively. In the case of annual total departures, it decreased from September 2008 year to September 2010 year and was in a trough in September 2010 year. It was forecast to increase in September 2011 year and then remain steady between September 2011 and 2012 years.

Based on these forecast results, annual net arrivals which were 4,386, 17,025 and 13,911 during September 2008 to 2010 years were forecast to decline to about 11,000 during September 2011 year and increase to about 14,000 during September 2012 year. After reaching a peak in September 2009 year, net arrivals declined somewhat. It was forecast to reach a trough in September 2011 year and then recover during September 2012 year to about September 2010 year levels.

\section{Conclusions}

We used the linear time series regression method or the seasonal multiplicative Holt-Winters exponential smoothing method to estimate the eight migration components disaggregated for analysis and to forecast the next eight or nine quarterly migration flows (two inflows and four outflows). Forecasts of migration flows for the next two years, for September 2011 and September 2012 years, were also generated. The forecasting framework met the following requirements: (1) Transparent; (2) Technically sound; (3) Ability to forecast out two years; (4) Capability for regular updates of forecasts. 
The results could be considered as very promising and as excellent starting point in forecasting migration flows at the Department of Labour. The arrival (migration inflow) equations were estimated at a slightly aggregate level with only differentiation of those who arrive as new migrants (under various immigration programs) from arrival of New Zealand citizens without any differentiation of their origin. Both of these equations resulted in very good forecast performance with MAPE values being less than $6 \%$.

The departure (migration outflow) equations while considering those who are New Zealand citizens separate from others (as for the Arrival equations) also looked at disaggregating the destination of migrants from New Zealand. This resulted in those leaving for Australia and for the UK separated from the rest. Here again the departure equations of NonNew Zealanders (or new migrants) resulted in the MAPE values of less than $8 \%$. The departure equations of New Zealand citizens to the UK and to Australia were estimated using the Holt-Winters method as the linear time series regressions of the transformed data were considered unsatisfactory.

Future research will focus on improving the forecast equations further by reducing some of the MAPEs of within-sample forecasts. In addition, we will consider the use of the number of residence applications as an additional independent variable of non-New Zealanders arrivals. This data could provide additional insights and improve these equations further. However at this stage this administrative dataset only goes back (electronically) to 1997 while the equations are generally estimated with quarterly PLT data from 1978 onwards.

\section{References}

Statistics New Zealand, Permanent and long-term (PLT) migration data, June 1978 - September 2010.

Statistics New Zealand via dX, New Zealand GDPs, June 1978 - June 2010.

Statistics New Zealand via dX, Australian GDPs, June 1978 - June 2010.

Statistics New Zealand via dX, British GDPs, June 1978 - June 2010.

Statistics New Zealand via dX, New Zealand Civilian Employment Levels, June 1978 - June 2010.

Statistics New Zealand via dX, Australian Civilian Employment Levels, June 1978 - June 2010.

Statistics New Zealand via $\mathrm{dX}$, British Civilian Employment Levels, June 1978 - June 2010.

Thomson N and Chan M. (1999). Forecasting External Migration, 2000 to 2004 June Years, Statistics New Zealand.

\section{Appendix A: Variables, Data Sources \& Periods of their Availability}

\section{Dependent Variables}

$>$ Arrivals of Non-New Zealanders (ANNZ) - SNZ - (Quarterly; March 1990 - September 2010)

$>$ Returning New Zealanders (RNZ) - SNZ (Quarterly; June 1978 - September 2010)

> Departures of Non-New Zealanders to Australia (DNNZTA) - SNZ (Quarterly; June 1978 September 2010)

D Departures of Non-New Zealanders to the UK (DNNZTU) - SNZ (Quarterly; June 1978September 2010)

$>$ Departures of Non-New Zealanders to the Rest of the World (DNNZTRW) - SNZ (Quarterly; June 1978-September 2010)

$>$ Departures of New Zealanders to the Rest of the World (DNZTRW) - SNZ (Quarterly; June 1978 September 2010)

\section{Independent Variables}

$>$ Corresponding Lagged Dependent Variables SNZ (Quarterly; September 1978 - September 2010 or March 1990 - September 2010 )

$>$ Total Departures of New Zealanders (TDNZ) SNZ (Quarterly; June 1978 - September 2010)

$>$ Arrivals of Non-New Zealanders (ANNZ) - SNZ - (Quarterly; June 1978 - September 2010)

$>$ The Ratio between the Changes of New Zealand and Australian GDPs (RCNZAG) - SNZ via dX (Quarterly; September 1978 - June 2010)

$>$ The Ratio between the Changes of New Zealand and Australian Civilian Employment Levels (RCNZACEL) - SNZ via dX (Quarterly; March 1986 - June 2010)

$>$ The Ratio between the Changes of New Zealand and British GDPs (RCNZBG) - SNZ via $\mathrm{dX}$ (Quarterly; September 1978 - June 2010)

$>$ The Ratio between the Changes of New Zealand and British Civilian Employment Levels (RCNZBCEL) - SNZ via dX (Quarterly; March 1986 - June 2010)

\section{Data Used in Holt Winters Method}

$>$ Departures of New Zealanders to Australia (DNZTA) - SNZ (Quarterly; June 1978September 2010)

$>$ Departures of New Zealanders to UK (DNZTU) SNZ (Quarterly; June 1978-September 2010) 


\section{Appendix B: Quarterly Forecasts, Annual actual data and Annual Forecasts}

Table 6: Quarterly Forecasts of Non-New Zealanders Arrivals and Returning New Zealanders

\begin{tabular}{|c|c|c|}
\hline Quarter & Forecasts of Non-New Zealanders Arrivals & Forecasts of Returning New Zealanders \\
\hline Dec. 2010 & 13,438 & 8,103 \\
\hline Mar. 2011 & 18,600 & 6,237 \\
\hline June 2011 & 12,187 & 4,723 \\
\hline Sept. 2011 & 16,915 & 5,692 \\
\hline Dec. 2011 & 14,415 & 8,096 \\
\hline Mar. 2012 & 19,860 & 6,263 \\
\hline June 2012 & 12,789 & 4,976 \\
\hline Sept. 2012 & 16,945 & 6,282 \\
\hline Dec. 2012 & 14,558 & 8,990 \\
\hline
\end{tabular}

Table 7: Quarterly Forecasts of Non-New Zealanders and New Zealanders Departures

\begin{tabular}{|c|l|l|l|l|l|l|}
\hline Quarter & $\begin{array}{l}\text { Forecasts of } \\
\text { Non-New } \\
\text { Zealanders } \\
\text { for Australia }\end{array}$ & $\begin{array}{l}\text { Forecasts of } \\
\text { Non-New } \\
\text { Zealanders } \\
\text { for UK }\end{array}$ & $\begin{array}{l}\text { Forecasts of Non- } \\
\text { New Zealanders } \\
\text { for the Rest of the } \\
\text { World }\end{array}$ & $\begin{array}{l}\text { Forecasts of } \\
\text { New } \\
\text { Zealanders for } \\
\text { Australia }\end{array}$ & $\begin{array}{l}\text { Forecasts of } \\
\text { New } \\
\text { Zealanders } \\
\text { for UK }\end{array}$ & $\begin{array}{l}\text { Forecasts of New } \\
\text { Zealanders for } \\
\text { the Rest of the } \\
\text { World }\end{array}$ \\
\hline Dec. 2010 & 1,395 & 826 & 5,121 & 7,276 & 895 & 1,815 \\
\hline Mar. 2011 & 1,578 & 1,001 & 4,654 & 10,083 & 1,555 & 2,463 \\
\hline June 2011 & 1,146 & 1,200 & 4,489 & 7,869 & 1,921 & 2,212 \\
\hline Sept. 2011 & 1,098 & 994 & 4,751 & 6,952 & 1,253 & 2,536 \\
\hline Dec. 2011 & 1,461 & 859 & 5,255 & 7,215 & 869 & 1,859 \\
\hline Mar. 2012 & 1,544 & 951 & 4,709 & 9,999 & 1,510 & 2,404 \\
\hline June 2012 & 1,242 & 1,141 & 4,738 & 7,803 & 1,865 & 2,185 \\
\hline Sept. 2012 & 1,166 & 1,058 & 4,918 & 6,893 & 1,216 & 2,468 \\
\hline Dec. 2012 & & & 5,377 & 7,154 & 843 & 1,829 \\
\hline
\end{tabular}

Table 8: Actual Data and Forecast of Total Arrivals, Total Departures and Net Arrivals

\begin{tabular}{|r|c|c|c|c|c|c|}
\hline \multicolumn{1}{|c|}{ Year Ended } & $\begin{array}{c}\text { Actual Total } \\
\text { Arrivals }\end{array}$ & $\begin{array}{c}\text { Forecasts of } \\
\text { Total Arrivals }\end{array}$ & $\begin{array}{c}\text { Actual Total } \\
\text { Departures }\end{array}$ & $\begin{array}{c}\text { Forecasts of Total } \\
\text { Departures }\end{array}$ & $\begin{array}{c}\text { Actual Net } \\
\text { Arrivals }\end{array}$ & $\begin{array}{c}\text { Forecasts of } \\
\text { Net Arrivals }\end{array}$ \\
\hline September 08 & $\mathbf{8 6 , 6 5 7}$ & $\mathbf{8 5 , 6 3 4}$ & $\mathbf{8 2 , 2 7 1}$ & $\mathbf{8 0 , 6 8 9}$ & $\mathbf{4 , 3 8 6}$ & $\mathbf{4 , 9 4 5}$ \\
\hline December 08 & 87,463 & 86,084 & 83,662 & 82,276 & 3,801 & 3,807 \\
\hline March 09 & 88,873 & 88,796 & 81,407 & 83,926 & 7,466 & 4,870 \\
\hline June 09 & 88,251 & 88,926 & 75,748 & 82,117 & 12,503 & 6,809 \\
\hline September 09 & $\mathbf{8 7 , 2 0 9}$ & $\mathbf{8 9 , 1 7 5}$ & $\mathbf{7 0 , 1 8 4}$ & $\mathbf{7 7 , 1 7 1}$ & $\mathbf{1 7 , 0 2 5}$ & $\mathbf{1 1 , 0 0 4}$ \\
\hline December 09 & 86,410 & 86,886 & 65,178 & 71,782 & 21,232 & 15,103 \\
\hline March 10 & 84,336 & 84,917 & 63,376 & 64,429 & 20,960 & 20,488 \\
\hline June 10 & 82,305 & 83,136 & 65,813 & 63,111 & 16,492 & 20,025 \\
\hline September 10 & $\mathbf{8 2 , 4 1 2}$ & $\mathbf{8 0 , 4 6 7}$ & $\mathbf{6 8 , 5 0 1}$ & $\mathbf{6 5 , 3 2 2}$ & $\mathbf{1 3 , 9 1 1}$ & $\mathbf{1 5 , 1 4 4}$ \\
\hline December 10 & & 80,671 & & 68,519 & & 12,152 \\
\hline March 11 & & 81,185 & & 72,843 & & 8,342 \\
\hline June 11 & & 82,427 & & 74,389 & & 8,039 \\
\hline September 11 & & $\mathbf{8 5 , 8 9 6}$ & & $\mathbf{7 5 , 0 8 1}$ & & $\mathbf{1 0 , 8 1 5}$ \\
\hline December 11 & & 86,865 & & 75,272 & & 11,593 \\
\hline March 12 & & 88,151 & & 75,055 & & 13,096 \\
\hline June 12 & & $\mathbf{8 9 , 6 2 6}$ & & $\mathbf{7 5 , 3 2 8}$ & & 13,814 \\
\hline September 12 & & & & $\mathbf{1 4 , 2 9 8}$ \\
\hline
\end{tabular}




\section{Appendix C: Full-sample Migration Equations}

(A) Arrivals

Equation 1: Arrivals of non-New Zealanders

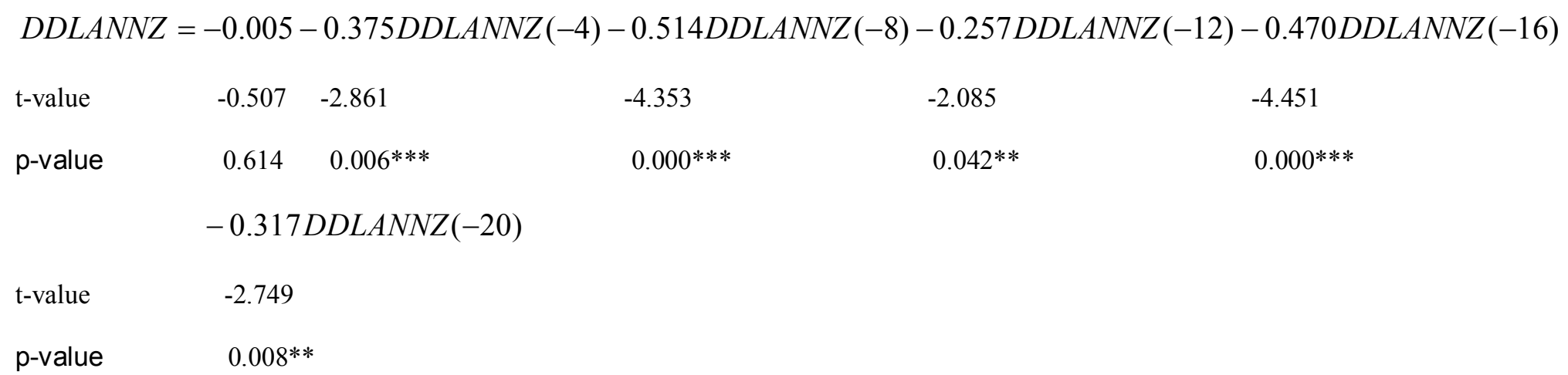

Equation 2: Returning New Zealanders

\begin{tabular}{|c|c|c|c|c|c|c|}
\hline t-value & 0.211 & -4.933 & -3.452 & -2.691 & -2.022 & -2.351 \\
\hline p-value & $0.080 *$ & $0.000^{* * * *}$ & $0.008 * * *$ & $0.000 * * *$ & $0.000 * * *$ & $0.000 * * *$ \\
\hline
\end{tabular}

R-squared $=0.353$, Adjusted R-squared $=0.321, \mathrm{~F}$-statistic $=11.015, \mathrm{AIC}=-2.446$

(B)Departures-Non-New Zealanders

Equation 3: Departures of non-New Zealanders to Australia

$D D L D N N Z T A=0.011-0.704 D D L D N N Z T A(-4)-0.455 D D L D N N Z T A(-8)-0.344 D D L D N N Z T A(-12)-0.160 D D L D N N Z T A(-20)$ 


$\begin{array}{llllll}\text { t-value } & 1.071 & -7.217 & -4.536 & -4.137 & -2.100 \\ \text { p-value } & 0.288 & 0.000 * * * & 0.000 * * * & 0.000 * * * & 0.039 * *\end{array}$

$-0.281 D D L A N N Z(-15)-0.003 R C N Z A G(-9)-0.009 R C N Z A C E L(-17)$

$\begin{array}{llcc}\text { t-value } & -2.470 & -1.937 & -2.444 \\ \text { p-value } & 0.016^{* *} & 0.057^{*} & 0.017^{* *}\end{array}$

R-squared $=0.543$, Adjusted R-squared $=0.500$, F-statistic $=12.571, \mathrm{AIC}=-1.874$

Equation 4: Departures of non-New Zealanders to the UK

\begin{tabular}{|c|c|c|c|c|c|}
\hline t-value & 0.332 & -7.085 & 2.790 & -5.493 & -3.581 \\
\hline $\mathrm{p}$-value & 0.197 & $0.000 * * *$ & $0.006 * * *$ & $0.000 * * *$ & $0.001 * * *$ \\
\hline \multicolumn{6}{|c|}{$-0.152 D D L D N N Z T U(-19)-0.209 D D L D N N Z T U(-20)+0.384 D D L A N N Z(-8)-1.87 \times 10^{-5} R C N Z B G(-12)$} \\
\hline t-value & -1.915 & & -2.987 & 3.461 & -5.948 \\
\hline p-value & $0.059 *$ & & $0.004 * * *$ & $0.001 * * *$ & $0.000 * * *$ \\
\hline
\end{tabular}

R-squared $=0.483$, Adjusted R-squared $=0.440$, F-statistic $=11.196$, AIC $=-1.764$

Equation 5: Departures of non-New Zealanders to the rest of the world

\begin{tabular}{|c|c|c|c|c|}
\hline t-value & 0.089 & -2.417 & 4.171 & -2.861 \\
\hline p-value & 0.990 & $0.018 * *$ & $0.000 * * *$ & $0.005 * * *$ \\
\hline
\end{tabular}




\section{$-0.288 D D L D N N Z T R W(-8)-0.168 D D L D N N Z T R W(-18)$}

t-value $\quad-4.144 \quad-2.346$

p-value $\quad 0.000^{* * *} \quad 0.021^{* *}$

$\mathrm{R}$-squared $=0.405$, Adjusted R-squared $=0.378, \mathrm{~F}$-statistic $=13.761, \mathrm{AIC}=-1.925$

(C) Departures-New Zealanders

Equation 6: Departures of New Zealanders to the rest of the world

\begin{tabular}{|c|c|c|c|c|c|}
\hline t-value & 0.438 & -1.879 & -6.201 & -2.340 & -4.101 \\
\hline \multirow[t]{2}{*}{ p-value } & 0.663 & $0.063^{*}$ & $0.000 * * *$ & $0.021 * *$ & $0.000^{* * *}$ \\
\hline & \multicolumn{5}{|c|}{$-0.254 D D L D N Z T R W(-12)-0.210 D D L D N Z T R W(-16)$} \\
\hline t-value & -2.501 & & -2.670 & & \\
\hline p-value & $0.014 * *$ & & $0.009 * * *$ & & \\
\hline
\end{tabular}

R-squared $=0.370$, Adjusted R-squared $=0.333$, F-statistic $=9.980$, AIC $=-2.034$ 